Article

\title{
Performance and Acceptance of Novel Silver-Impregnated Ceramic Cubes for Drinking Water Treatment in Two Field Sites: Limpopo Province, South Africa and Dodoma Region, Tanzania
}

\author{
David M. Kahler ${ }^{1, *,+}$, Natasha T. Koermer ${ }^{2,+}$, Allison R. Reichl ${ }^{3,+}$, Amidou Samie ${ }^{4}$ and \\ James A. Smith ${ }^{1}$ \\ 1 Department of Civil and Environmental Engineering, University of Virginia, Charlottesville, VA 22904, USA; \\ jsmith@virginia.edu \\ 2 Department of Biomedical Engineering, Univerity of Miami, Coral Gables, FL 33146, USA; \\ n.koermer@umiami.edu \\ 3 Department of Bioengineering, University of California, Berkeley, CA 94704, USA; areichl@berkeley.edu \\ 4 Department of Microbiology, University of Venda, Thohoyandou, Limpopo 0950, South Africa; \\ samieamidou@yahoo.com \\ * Correspondence: david.m.kahler@gmail.com; Tel.: +1-202-630-8757 \\ + These authors contributed equally to this work.
}

Academic Editor: Miklas Scholz

Received: 20 December 2015; Accepted: 29 February 2016; Published: 10 March 2016

\begin{abstract}
Diarrheal disease and environmental enteropathy are serious public health concerns in low-income countries. In an effort to reduce enteric infection, researchers at the University of Virginia developed a new point-of-use (POU) water treatment technology composed of silver-impregnated porous ceramic media. The ceramic is placed in a $15 \mathrm{~L}$ plastic container of water in the evening and the water is ready to drink in the morning. The purpose of this study was to assess field performance and local acceptance of technology in two communities in Limpopo Province, South Africa, and one community in Dodoma Region, Tanzania. Performance was determined by coliform testing of treated water. Acceptance was determined using data from 150 household surveys and a nine-day structured observational study at a local primary school. At the primary school, 100\% of treated water samples had no detectable levels of total coliform bacteria (TCB) in buckets filled by researchers. For all treated school buckets, $74 \%$ of samples achieved less than or equal to $1 \mathrm{CFU} / 100 \mathrm{~mL}$ and 3.2 average $\log$ reduction of TCB. Laboratory experiments with highly contaminated water diluted to lower turbidity achieved 4.2 average $\log$ reduction of TCB. Turbid water (approximately 10 NTU) only achieved 1.1 average log reduction of TCB; turbidity and organic material may have interfered with disinfection. The Tanzania primary school (deep groundwater source) had less turbid water and achieved 1.4 average log reduction of TCB; however, it did have high chloride levels that may have interfered with silver disinfection. The surveys revealed that the majority of people retrieve, store, and dispense water in ways that are compatible with the new technology. The willingness-to-pay study revealed potential customers would be willing to pay for the technology without subsidies. The results of this study indicate that this novel silver-impregnated ceramic POU water treatment technology is both effective and appropriate for use in the study communities.
\end{abstract}

Keywords: drinking water; water treatment; water disinfection; water purification; social entrepreneurship; international development 


\section{Introduction}

Worldwide, diarrheal disease is a leading cause of mortality [1] and accounts for $15 \%$ of all deaths among children under the age of 5 . In recent decades, the number of diarrheal deaths has dropped due to improved case management and effective oral rehydration therapy [2]. However, the prevalence of early childhood enteric infection has been correlated with subsequent diminished school performance as well as impaired cognitive and physical function [1,3]. Such stunting has been termed environmental enteropathy [4]. Early studies suggest that chronic exposure to fecal pathogens leads to intestinal inflammation and blunting of the intestinal villi. Furthermore, long-term inflammation can cause permanent structural changes in the intestinal wall, contributing to malnutrition, poor nutrient absorption, and impaired immune response [5]. Studies in South America have shown that enteroaggregative E. Coli and Cryptosporidium infections, even without diarrheal symptoms, predispose children to growth stunting [6].

Drinking water treatment is an important step to reduce the risk of diarrheal disease and environmental enteropathy. Point-of-use (POU) water treatment is lauded as a low-cost, effective, and scalable method for water disinfection; a meta-analysis demonstrated that POU water treatment is more effective than centralized water treatment systems in resource-limited regions at improving water quality, and thus reducing diarrheal disease [7]. The World Health Organization recognizes the important role of POU water treatment and recommends, "properly formulated and locally relevant performance specifications are needed to protect users and inform decision-making regarding selection of technologies or approaches" [8]. Ceramic water filters have been at the center of many studies with good results in social acceptability, economic viability, and environmental sustainability-the so-called "triple bottom line" [9]. Even so, in their recent water filter evaluation report, MIT reported that low-priced water filters are not sufficient for reaching many rural populations and more non-electric treatment technologies are needed [10].

In an effort to reduce environmental enteropathy and diarrheal infection, researchers at the University of Virginia developed a silver-impregnated porous ceramic technology (Figure 1), an entirely new water treatment technology that diffuses silver ions to reduce pathogens [11,12]. Ceramic cubes that contain silver nanopatches within their pores are placed in a household bucket or jerry can, and silver ions diffuse out of the ceramic matrix and into the stored water. Treatment takes eight hours; the instructions suggest filling the container at night in order for the water to be ready for consumption in the morning. The ceramic cubes last for six months of daily use. Users can leave the ceramic cubes in the water container so treatment does not require any additional steps. Ceramic cubes only need to be removed when cleaning the container.

Silver ions are effective against bacteria [13-15] and protozoa [16]; furthermore, they are more effective than chlorine against Cryptosporidium [17-19]. Viruses [20] and helminthes [21] are also susceptible to silver ions. Silver, at safe yet effective concentrations, imparts no taste or color to the treated water. Dissolved oxygen concentration controls the release rate of silver ions [22]; although, other substances have been shown to affect silver availability, such as $\mathrm{pH}$, chloride, and organic material [23].

The other options for water treatment include filtration, boiling, and the use of other chemicals. Filters can be made locally with local materials [24]. However, filters are also large and fragile; researchers observed that in the rural communities of South Africa, where most of this work was conducted, filters frequently fractured in transit over rough dirt roads. Furthermore, filters are still too expensive or not available for many rural residents [10]. Boiling is another effective means for water treatment; however, it requires burning fuel, which can decrease indoor air quality and increase greenhouse gases. Perhaps most important to the consumer in the short-term, boiling water requires time and leaves the water less palatable. Chlorine is the most common POU treatment chemical. Unfortunately, devices that automatically provide the proper dose of the chemical are expensive and manual methods rely on the consumer to remember to obtain and dose each batch of water. Additionally, some people dislike the taste of chlorine so much that they discontinue routine use [25-29]. 


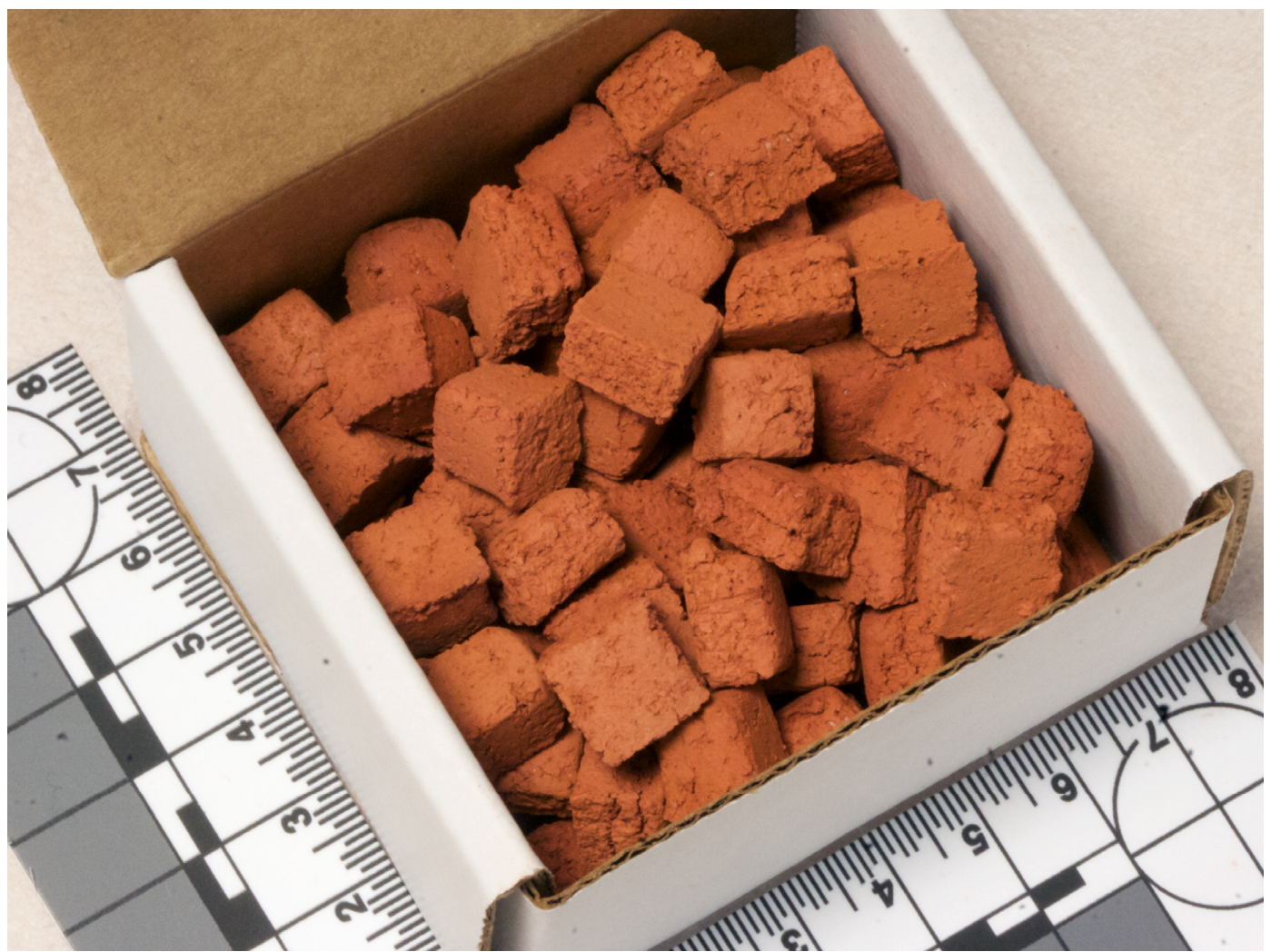

Figure 1. A single package of the silver-impregnated porous ceramic pieces used in the study. Scale shown is in centimeters $(\mathrm{cm})$.

\subsection{Demographics}

This research was conducted in three communities: communities A and B in the Vhembe District of Limpopo Provence, South Africa, and community C in the Dodoma Region, Tanzania. According to the 2001 census of South Africa, communities A and B have 584 and 471 households respectively, with a population of 2610 and 1952, respectively [30]. According to data from the Tanzania Ministry of Water, Dodoma Region office, community C has a population of 3316 people [31]. Researchers obtained demographic and water use data from 50 households in each of these communities. Communities A and B have customary chiefs as community leaders and fall under a complex cultural leadership organization with familial succession. All communities have water committees that manage various aspects of drinking water provision.

Basic demographic information was collected in a brief census conduced prior to the surveys in each of the communities. There is a characteristic youth bulge in all of the communities with $55 \%, 65 \%$, and $59 \%$ of the population under 30 years of age in communities $\mathrm{A}, \mathrm{B}$, and C, respectively (Figure S1a-c). There are notable differences in the income level between communities A and B, and community $\mathrm{C}$; specifically, respondents from communities $\mathrm{A}$ and $\mathrm{B}$ generally have higher incomes than those from community C (Figure S2). Communities A and B are connected through public transportation options multiple times a day to urban centers where there are employment options and cash-based trade opportunities. Community $\mathrm{C}$ has limited public transportation to urban centers. The community leaders and interpreters informed researchers that community $\mathrm{C}$ and the surrounding area rely almost entirely on agriculture and bartering; cash transactions are rare. In addition to income, there are notable differences in the level of formal education between communities $\mathrm{A}$ and $\mathrm{B}$, and community $\mathrm{C}$; specifically, respondents from communities $\mathrm{A}$ and $\mathrm{B}$ generally have attained a higher level of formal education than those in community C (Table S1). 


\subsection{Water Access}

Community A has its own self-funded water distribution system where water is drawn from a borehole and distributed through a community pipe network. The community water committee manages the water distribution system; operations and maintenance are funded through general fees that are not associated with consumption amount. Some sections of the community have water available each day although most sections have availability two to three days per week. Residents predominantly collect water from public standpipes. When the community boreholes are dry or contaminated, residents purchase water from wealthy neighbors' private boreholes. Six percent of families in community A reported having a private borehole.

Community B has a water treatment and distribution system, located approximately $10 \mathrm{~km}$ away, that is operated by the municipality and funded by taxes. Water services are scheduled for two days per week in the study community and rotate to other communities on other days. In practice, the supply is inconsistent; when this research was conducted, the water treatment plant had been shut down for over a month because of a broken intake pipe. Most members of community B collect water from public standpipes. When the public standpipes are off, residents must gather water from the irrigation canal above community B, a spring, or the nearby river. Use of these surface water resources, compared to standpipe water, increases the travel time by a factor of ten for most households.

Community $C$ has a deep well with a diesel-powered pump that supplies two large holding tanks that are connected to a distribution system. Access to the community taps is regulated; every standpipe is locked and residents who want to gather water must call a member of the water committee to unlock it. Residents pay a fee based on the number of jerry cans filled. Of those surveyed, $78 \%$ reported that they believe the tap water is of high quality; although only $40 \%$ use the public tap as their primary water source while $58 \%$ use a shallow, hand-dug well in the dry season. The shallow, hand-dug wells are not as productive in the dry season and more residents obtain water from the community taps; however, in the wet season, the shallow wells are more productive and more residents use them. Water from the shallow wells is collected by shoveling sand away from the bottom and transferring the water, less than one liter at a time, into a bucket. It is customary to filter turbid or cloudy water with two layers of commonly available cloth called a kanga.

\section{Materials and Methods}

The protocol described in this manuscript was approved by the Institutional Review Boards (IRB) of the University of Virginia: No. SBS-2015018100 and the University of Venda: No. SMNS/15/MBY/08/0306.

This study investigated the performance of a novel silver-impregnated ceramic for water disinfection [32]. The water treatment intervention tested here consisted of approximately 100 ceramic cubes, each approximately $1 \mathrm{~cm}^{3}$ in volume, and packaged in a single box of about $130 \mathrm{~g}$ (Figure 1 ). Additionally, the ceramic technology was distributed with locally available $22 \mathrm{~L}$ plastic buckets that had lids and spigots to reduce the risk of recontamination during retrieval of water. The cubes were produced at a facility at the University of Virginia according to the method described by Ehdaie et al. [33]. To disinfect 5-15 L of water, the ceramic cubes were placed in a bucket of water for at least eight hours. The dissolved oxygen in the water oxidized the silver nanopatches, which released silver ions. The silver ions diffused out of the porous ceramic and into the water.

\subsection{Performance Testing}

Researchers conducted performance tests in primary schools in communities A and C, and in the laboratory with highly contaminated water from a source near University of Venda not used as a drinking water supply. Buckets were cleaned to remove any manufacturing residue and a set of ceramic pieces was placed in the bottom. Any ceramic used for treating water for consumption was soaked for a minimum of $10 \mathrm{~h}$ prior to use. 
The water source at the primary school in community A was a deep borehole, separate from the community system, that was pumped into two 10,000 L tanks that supply a central tap in the school courtyard and two other taps near the administration building and the kitchen (Figure 2a). A separate $10,000 \mathrm{~L}$ tank and tap were located on the perimeter of the property and supply a small garden. Each classroom had a drinking water bucket in front of the door with a communal cup. Students dipped the cup into the bucket to retrieve drinking water. At the primary school in community C (Figure 2b), students and staff had access to the community water supply; there was no water placed closer to the classrooms. At the time of intervention, researchers supplied a bucket with spigot and ceramic cubes for the fourth and seventh grade intervention classrooms. Students provided their own cups.

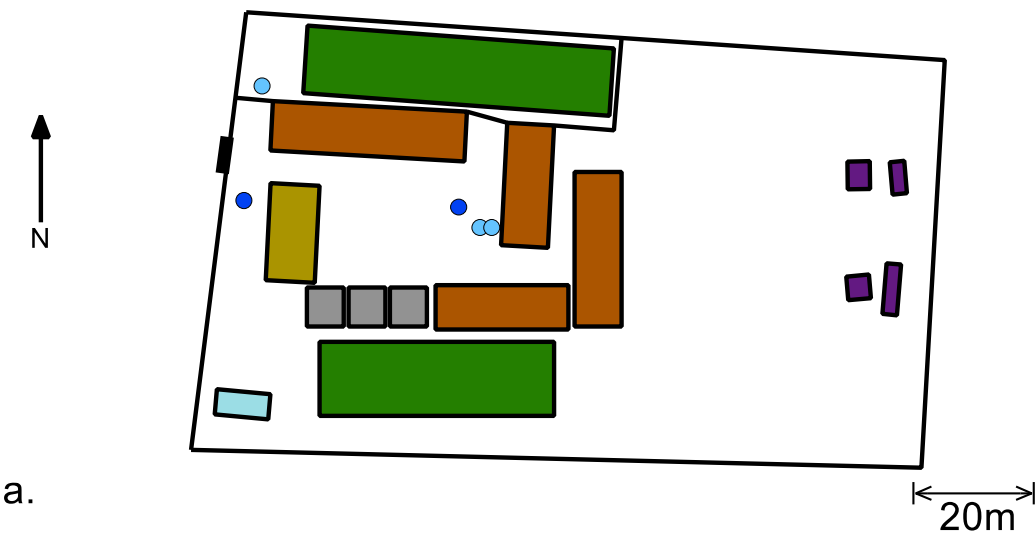

b.

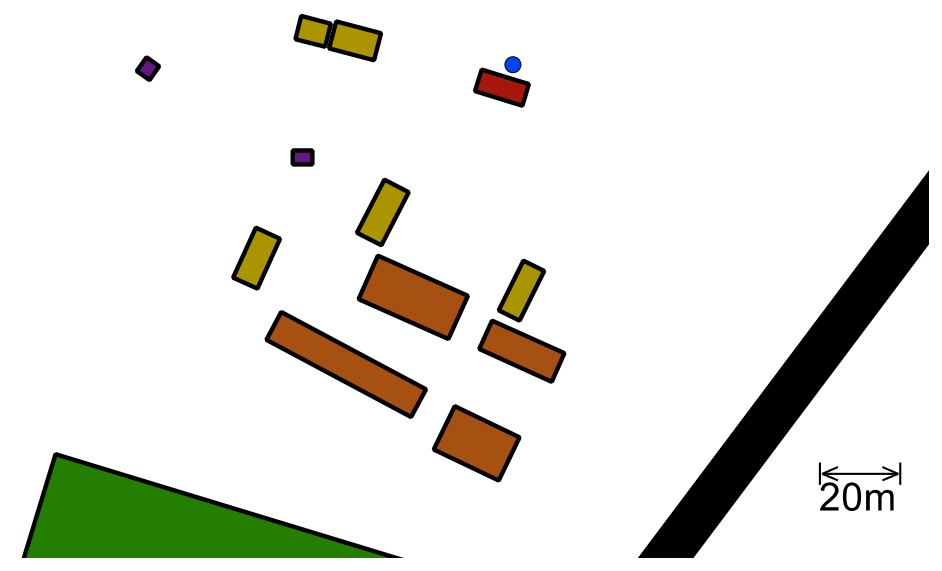

Figure 2. Plan of the primary schools in (a) community A and (b) community C. Classroom buildings (brown), administrative (yellow), latrines (purple), and water taps (dark blue) and tanks (light blue) are shown. Community A had a fence around the school grounds with one gate shown on the left. The school also had two gardens (green) and a kitchen (blue) that served lunch everyday. The school in community $\mathrm{C}$ had a clinic nearby (maroon) next to the water tap. The northernmost classroom building had a rainwater harvesting system that is only usable in the rainy season and, at present, is an unknown state of functionality. In community $\mathrm{C}$, the main road is shown in the southeast corner (small roads are not shown). In both communities, the researchers recorded observations from a central vantage point: in community A, between the eastern and southern classroom buildings; in community $\mathrm{C}$ at the eastern end of the courtyard between classroom buildings.

Buckets were filled with approximately $15 \mathrm{~L}$ of water for the school (school tap for community A and community tap for community C) and 5-15 L of highly contaminated water in the laboratory. After the buckets were filled, water quality parameters were obtained. Water quality parameters were measured at most fillings via $\mathrm{pH}$ probe $(\mathrm{pH})$, a chloride ion-selective electrode $\left(\mathrm{Cl}^{-}\right.$concentration), dissolved oxygen probe (concentration dissolved $\mathrm{O}_{2}$ ), and turbidity meter (turbidity in Nephelometric 
turbidity units or NTUs). These probes connected to a Vernier LabView 2 console (Vernier Software and Technology, Beaverton, OR, USA). Due to sensor failure at the community C site, dissolved oxygen and temperature were obtained from a Fisher Scientific field probe (Fisher Scientific, Pittsburgh, PA, USA), while $\mathrm{pH}$ and turbidity were obtained from samples stored until replacement sensors were available at the field site.

The test buckets for the four classrooms (one bucket each) had a set of ceramic pieces inside and stored in the classroom overnight and placed in front of the door during class; the control buckets had no ceramics and were stored in the administration building in community $\mathrm{A}$ and in the clinic in community $\mathrm{C}$. The buckets in the schools were filled at the conclusion of each school day, usually between 13:00 and 17:00, and not used until 07:30 the next morning. In the case of the water for Mondays, the buckets were filled at the end of classes on Friday. Samples were obtained at approximately 09:30 in community A and 08:30 in community C. Due to the distance between community $\mathrm{C}$ and the laboratory in Dodoma, bacterial samples were only obtained on Fridays. Samples from each of the buckets were obtained through a clean catch through the spigot by opening the spigot in the bucket fully open for at least $30 \mathrm{~s}$, closing the spigot, and opening it again to fill the sample bag for microbiological analysis and vial for silver analysis.

Microbiological measurements were made based on the U.S. Environmental Protection Agency method 10023; occasionally, due to the remote location of the sites, some samples were measured outside of the recommended six-hour limit. Samples were transported in an insulated container between collection and testing sites. Microbiological samples were tested for total coliform and $E$. Coli via membrane filtration. At the South African laboratory, the sample cups of the manifold were rinsed and placed in a hot water bath set to $100{ }^{\circ} \mathrm{C}$ for a minimum of 20 minutes and flushed with reverse osmosis water. At the Tanzanian laboratory, the manifold and sample cups were cleaned with local municipal tap water and two complete flushes of boiling reverse osmosis water. Boiling water flushes were allowed to rinse through the junction of the sample cup and filter paper holder to ensure a completely clean surface. Sterile, individually packaged, $4.5 \times 10^{-7} \mathrm{~m}$ pore filter paper disks (EMD Millipore, Billerica, MA, USA) were transferred to the surface of the manifold with forceps with an aseptic technique. Depending on the precision desired, $100-300 \mathrm{~mL}$ of treated water samples or $0.1 \mathrm{~mL}$ ( $10^{-3}$ dilution) to $100 \mathrm{~mL}$ of control sample were passed through the filters. The filter paper was transferred by aseptic technique to a sterile petri dish with absorbent pad. A sterile, $2 \mathrm{~mL}$ ampule of selective growth media solution (m-ColiBlue24, EMD Millipore) was added to the petri dish. The petri dishes were incubated at $35^{\circ} \mathrm{C}$ for $23-25 \mathrm{~h}$.

Water samples analyzed for silver content. Researchers added $0.14 \mathrm{~mL}$ of $70 \%$ nitric acid (Fisher Chemical) to the $5 \mathrm{~mL}$ samples to reduce silver ion chelation. Total silver was measured with a graphite furnace (HGA 900, Perkin-Elmer, Waltham, MA, USA) atomic absorption spectrometer (AA2100, Perkin-Elmer).

\subsection{Chloride Interaction Tests}

Researchers prepared a stock E. Coli solution and divided it into batch reactors plus one control reactor of $100 \mathrm{~mL}$ each. The batch reactors were divided into two sets and dosed with silver ions of different concentrations. Within each set, a range of chloride ion concentrations was introduced. After eight hours, samples from the disinfection sets and control were tested for bacteria.

To obtain viable E. Coli, frozen stock (IDEXX Laboratories, Inc., Westbrook, ME, USA) was thawed and mixed with Luria-Bertani (LB) Broth. To make the LB Broth, $10 \mathrm{~g} / \mathrm{L}$ yeast extract (Sigma-Aldrich, St. Louis, MO, USA) was mixed with $10 \mathrm{~g} / \mathrm{L}$ sodium chloride (Fisher Chemical, Fair Lawn, NJ, USA) and $5 \mathrm{~g} / \mathrm{L}$ bacto-tryptic soy broth (Becton, Dickson and Company, Sparks, MD, USA) in deionized water $(\approx 18 \mathrm{M} \Omega$, Thermo Fisher, Fair Lawn, NJ, USA) and sterilized in an autoclave (Tuttnauer Brinkmann, 3545E-B/L, Hauppauge, NY, USA). The bacteria in LB broth was incubated at $37^{\circ} \mathrm{C}$ for $24 \mathrm{~h}$. Each reactor was inoculated with $0.1 \mathrm{~mL}$ of the $E$. Coli LB broth mixture. The bacteria were mixed in a phosphate buffer (PB) solution to maintain bacterial viability but retard growth before disinfection 
experiments. The PB solution was formulated with $1.12 \mathrm{~g} / \mathrm{L}$ of phosphate dibasic (Fisher Chemical) and $0.48 \mathrm{~g} / \mathrm{L}$ of potassium phosphate monobasic (Sigma-Aldrich) in deionized water and sterilized. Each batch reactor was treated with silver ions (from silver nitrate, Acros Organics, NJ, USA); one set at $6 \mathrm{ppb}$ and the other set at $12 \mathrm{ppb}$. Each reactor was also dosed with a range of chloride concentrations (from calcium chloride, Fisher Chemical). A control bucket, without silver or chloride was compared to the buckets with silver and chloride ions. Samples were taken and the antibacterial activity of the silver was quenched by the addition of $2.64 \mathrm{~mL}$ of $60 \mathrm{~g} / \mathrm{L}$ of sodium thiosulfate (Fisher Chemical). The bacterial levels were measured by the most-probable number technique with Colilert Quanti-Tray, Standard Method 9223B with Colilert media and IDEXX Quanti-Trays (IDEXX Laboratories, Inc.).

\subsection{Acceptance}

A primary school in community A was used to test the local acceptance of the water treatment technology through a drinking water intervention. At the school, four classrooms were observed, two classes in fourth grade and two in seventh grade. Each class had about 30 students. Before starting the study, researchers notified students and parents of the study and informed them how to exercise their option to not participate.

Observations occurred over three periods of one week each, identified here at T1, T2, and T3. Researchers observed and recorded the hygiene and drinking water habits of students from a central vantage point in the school courtyard (Figure 2). Researchers observed students for three days in each observational period. The first observation period, T1, established baseline behavior. Students used their usual drinking water facilities; the water treatment was not yet offered. Researchers observed the drinking water consumption of the students. In the second observation period, T2, water treated with the silver-embedded ceramic technology was offered adjacent to the students' normal drinking water containers. Students were not instructed on the technology's use, and students still had access to their usual drinking water source. The researchers or school administrators refilled the water buckets and placed them in the classrooms overnight. In the morning, the students placed the buckets with treated water outside the classrooms next to the bucket with untreated water. Researchers observed if there were any changes in use of the drinking water. In the final observation period, T3, researchers delivered an educational module in their classrooms, provided the treated water, and observed drinking water use.

The one-hour module was instructed in the local language, Tshivenda, by one of the research assistants during regular school hours while the teacher observed each classroom. To develop the curriculum, researchers first consulted with the teachers to discuss appropriate topics and activities for the location and age groups and used available educational resources (Document S1). The curriculum covered the health benefits of drinking water, germ theory, basic microbiology, healthy hand-washing methods, water treatment methods, and proper water storage. In the water treatment section, researchers explained locally common water treatment techniques and, specifically, the ceramic water treatment technology used in the school and how it functions. The lessons were delivered with hands-on activities to engage the students throughout the module.

\subsection{Priorities and Valuation}

In communities A and B, researchers met with the traditional chiefs and identified several sections of the community where they were allowed to conduct surveys; within each section, houses were chosen at random. Researchers verified that the sections of houses were distributed geographically throughout the communities. In community $C$, the Anglican Church, a parish of the Anglican Diocese of Central Tanganyika, operates an orphan placement program with volunteer families in the community. Survey subjects were selected from the group of families that have accepted orphans; it is not possible to determine that these families were a representative sample.

Researchers administered a survey to 50 households in each of the three communities that included questions about their current water treatment practices and a willingness-to-pay study. 
Native speakers of the community languages (Tshivenda in communities A and B, and Kigogo in community $\mathrm{C}$ ) who were also fluent in English interpreted the survey and responses. In communities $A$ and $B$, the survey was performed in conjunction with the demographic surveys reported in Section 2. In community $\mathrm{C}$, the survey was administered to families separately from the demographic study. The survey questions were intended to determine the behaviors around drinking water procurement and storage. The key questions that we report were:

1. "What, if anything, do you use to treat your water?"

2. "What do you use to retrieve water from its storage vessel?"

3. "What are the three most important water treatment characteristics, in no particular order, to you and your family?"

After the survey questions, the researchers explained the function and proper usage of the silver-impregnated porous ceramic technology to the household respondent. The household respondent was then presented with a range of potential prices for the ceramic technology as well as the option to not pay any of the choices. There were three ranges of prices presented based on the cost of production of the technology, which is approximately 3 USD. The purpose of these ranges in the willingness-to-pay survey was to determine if the technology could be sold at a price above the cost of production (unknown profit margin, sustainable business model), at the cost of production (little to no profit margin but may cover costs), or below the cost of production (subsidies required to distribute the technology). Respondents were presented with an above cost, at cost, or below cost range (Table 1) and were asked to choose which price in the range they would be willing to pay for the ceramic technology.

Table 1. The three ranges of prices offered in the willingness-to-pay survey. The ranges are based roughly on the cost of production of the technology. The offered prices were in the local currency and are shown below converted into United States Dollars based on the six month average conversion rate leading up to the survey period.

\begin{tabular}{ccccc}
\hline \multirow{2}{*}{ Range } & \multicolumn{2}{c}{ Community A and B } & \multicolumn{2}{c}{ Community C } \\
\cline { 2 - 5 } & $\begin{array}{c}\text { South African } \\
\text { Rand (ZAR) }\end{array}$ & $\begin{array}{c}\text { United States } \\
\text { Dollars (USD) }\end{array}$ & $\begin{array}{c}\text { Tanzanian } \\
\text { Shillings (TZS) }\end{array}$ & $\begin{array}{c}\text { United States } \\
\text { Dollars (USD) }\end{array}$ \\
\hline \multirow{3}{*}{ Below } & 30 & 2.48 & 3500 & 1.76 \\
& 35 & 2.90 & 4000 & 2.02 \\
& 40 & 3.31 & 4500 & 2.27 \\
At cost & 40 & 3.31 & 5500 & 2.77 \\
& 45 & 3.73 & 6000 & 3.02 \\
& 50 & 4.14 & 6500 & 3.27 \\
\multirow{3}{*}{ Above } & 55 & 4.56 & 7500 & 3.78 \\
& 65 & 5.38 & 8000 & 4.03 \\
\hline
\end{tabular}

To validate the willingness-to-pay study, researchers offered the technology for sale at the price evaluated in the survey; if the household agrees to purchase the technology, the price evaluated is a valid measurement of willingness-to-buy. In all of the communities included, sales were not done at the time of survey because households typically do not have cash available. Sales were conducted at predetermined times and respondents and community leaders were notified of those times in advance. In community A, the ceramic cubes were sold at the local ceramic factory for three Fridays during the month in which the research was conducted. The surveyed community members were informed that the ceramic technology was available for purchase on these days at the price that they selected in the survey. Due to the small number of research subjects and their geographic proximity, respondents were not actually sold the technology at different prices but charged a uniform price to reduce potential 
conflicts. When the respondent attempted to purchase the technology at their reported price, they were sold the product at a standard rate of 30 ZAR (approximately 2.48 USD). Respondents that arrived to purchase were counted as "willing to buy." Community B was not included in the willingness-to-buy component because residents were receiving ceramic water filters made possible by a philanthropic organization separate from this study. In community $C$, the ceramic cubes were sold at the local church for one week at the end of the survey period. In addition to the methodology and prices described for community A, respondents from community $\mathrm{C}$ were offered a work-for-pay option to purchase the technology. The community $C$ work option was three hours of manual labor, which at the local labor rates was approximately worth 6000 TZS (approximately 3.02 USD) [34].

\section{Results}

\subsection{Performance Testing}

Trials in the primary school in community A showed a significant reduction of bacteria in the drinking water. Of the buckets provided for consumption by students that were filled by researchers, $100 \%$ achieved no detection of total coliform bacteria and of all buckets measured at the school and of all buckets, $74 \%$ achieved less than or equal to $1 \mathrm{CFU} / 100 \mathrm{~mL}$ (colony forming units). Of all of the buckets tested at the primary school in community $\mathrm{A}$, the average log reduction relative to the control was $-\log _{10}(\mathrm{~T} / \mathrm{C})=3.2$ where $\mathrm{T}$ is the average total coliform in the treatment bucket and $\mathrm{C}$ is the average total coliform in the control bucket (Figure 3). This reduction is likely a conservative estimate due to the number of buckets that were below the detection limit; therefore, it is impossible to determine the true bacterial reduction. Of the highly contaminated laboratory tests with water diluted to a low turbidity ( $<5 \mathrm{NTU}$ ), the average log reduction relative to the control was 4.2. Furthermore, of the highly contaminated laboratory tests using higher turbidity water (11 NTU), the average log reduction relative to the control was 1.1. The highly contaminated water was also yellow in color. The water quality parameters measured at the primary school were within the limits of the South African National Standards Target Water Quality Range for $\mathrm{pH}$, chloride, and turbidity.

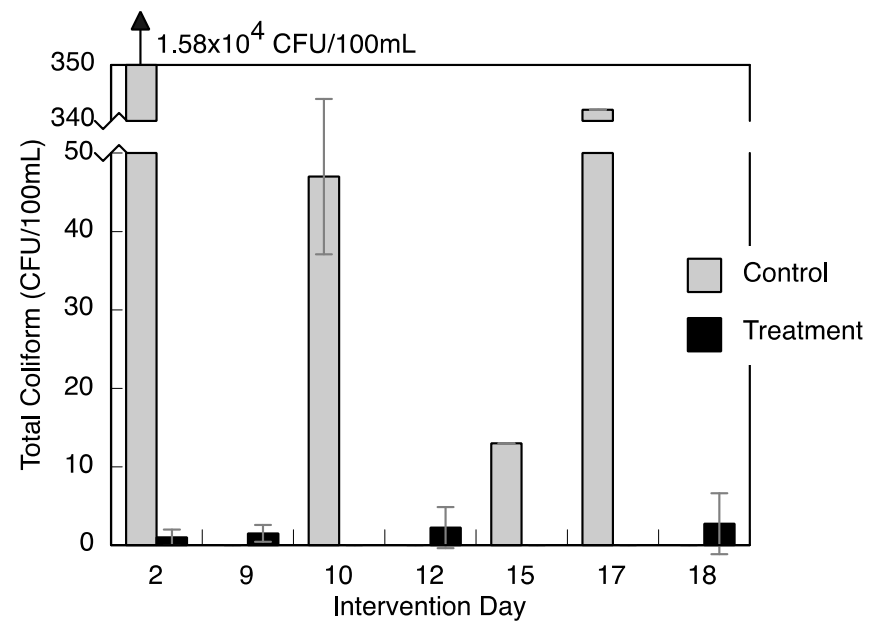

Figure 3. Performance results from the school study in community A. Measurements of total coliform in colony forming units per $100 \mathrm{~mL}$ of sample (CFU/100 mL) from the control buckets that had no treatment (gray) and the average of the four treatment buckets (black). The control value on the second intervention day was $1.58 \times 10^{4} \mathrm{CFU} / 100 \mathrm{~mL}$, too high to be displayed on the figure. On several days, control bucket total coliform levels were not available and those data are absent. Although, every day presented had treatment bucket coliform measurements; Days 10, 15, and 17 had no coliform detected.

Trials in the primary school in community $\mathrm{C}$ also reduced bacteria in the drinking water to low levels; however, the water in community $\mathrm{C}$ did not have as high total coliform levels in control 
buckets as community A. Of the buckets provided for consumption by students, $60 \%$ achieved less than or equal to one CFU / $100 \mathrm{~mL}$ of total coliform. Of all the buckets tested in community C, the average $\log$ reduction was $-\log _{10}(\mathrm{~T} / \mathrm{C})=1.4$ (Figure 4$)$. The water quality parameters measured were within Tanzanian standards and World Health Organization recommendations; however, the chloride levels, for which there is no standard or recommendation, was $325 \mathrm{mg} / \mathrm{L}$ on average, higher than the U.S. Environmental Protection Agency standard of $250 \mathrm{mg} / \mathrm{L}$ (for comparison, the Ministry of Water measurements are available in Dataset S3 [31]). This was in contrast to the average community A chloride level of $31 \mathrm{mg} / \mathrm{L}$.

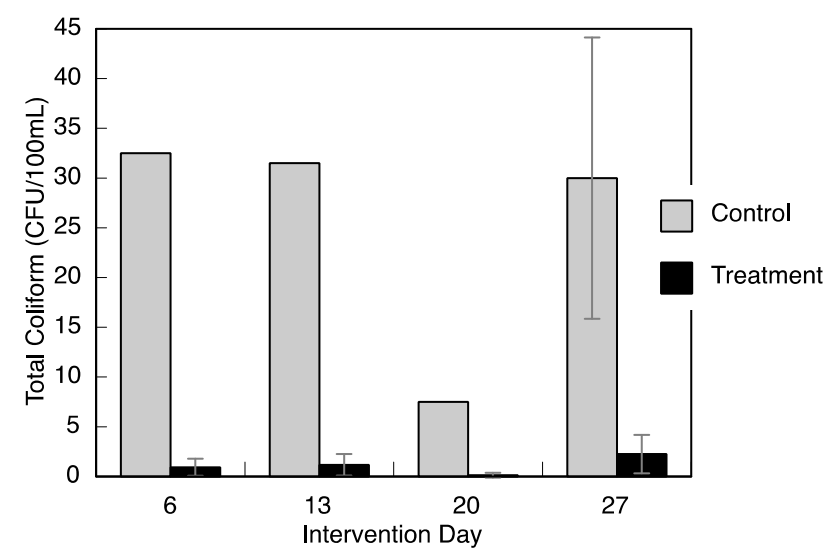

Figure 4. Performance results from the school study in community C. Measurements of total coliform from the control buckets that had no treatment (gray) and the average of the four treatment buckets (black).

The overall performance of the silver-impregnated porous ceramic cubes, as measured with the water from the primary school in community A and the challenge water from Thohoyandou was measured in terms of reduction in total coliform bacteria (Figure 5).

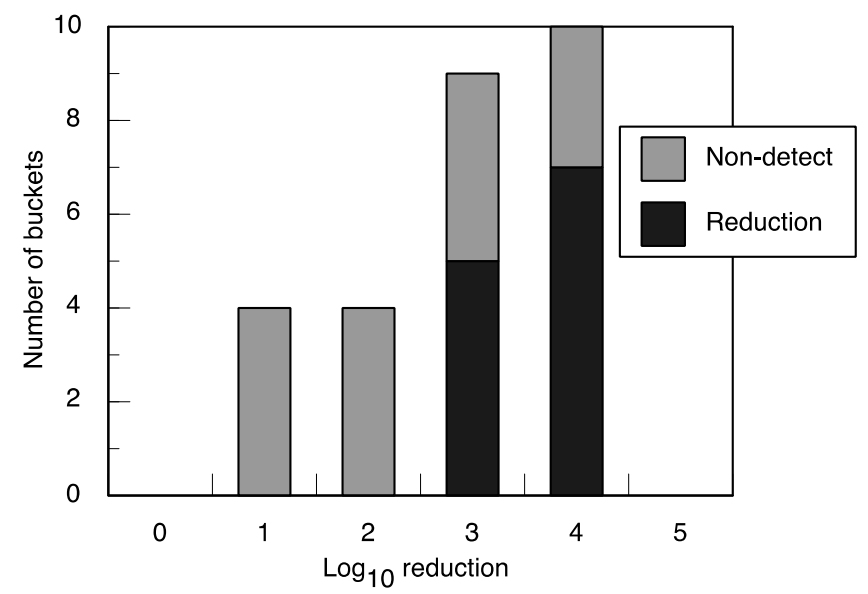

Figure 5. Histogram of the reduction of total coliform bacteria in the buckets at the primary school in community A and laboratory tests of low-turbidity water $(n=27)$. Reduction was calculated with the amount of bacteria in the treated bucket or the detection limit if no bacteria was detected. Of the 27 buckets, 15 had no coliform detected (gray); therefore, these buckets potentially represent an underestimate of the disinfection capability (the logarithm of the reduction was calculated with the detection limit in place of the end bacterial count). The remaining 16 buckets had some bacteria remaining and better indicate the potential disinfection capability. 
Treated water was tested for silver content by graphite furnace atomic absorption spectrometry (Figure 6). The total silver measured never exceeded half of the U.S. Environmental Protection Agency Secondary Drinking Water Standard or the World Health Organization recommendation. All of the data are provided in Dataset $\mathrm{S}$.

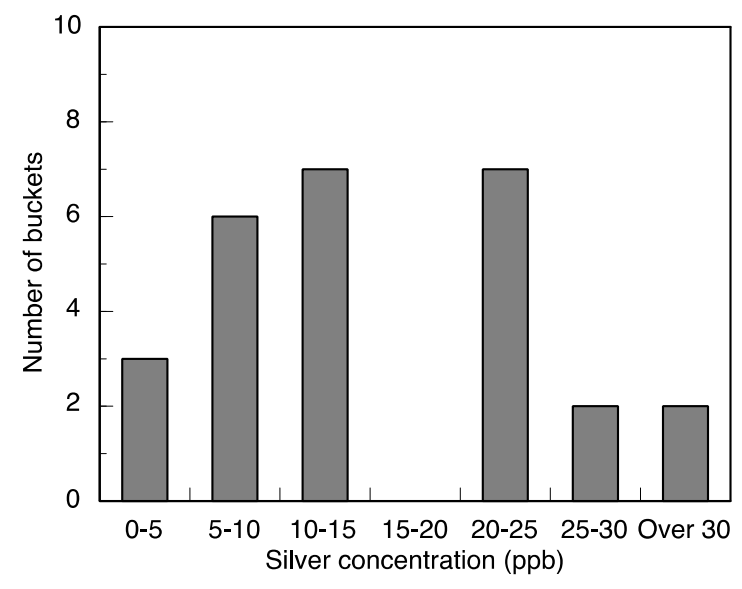

Figure 6. Histogram of the silver released in the buckets at the primary school in community A and laboratory tests of low-turbidity water $(n=27)$. Total silver was measured by a graphite furnace atomic absorption spectrometer.

\subsection{Chloride Interaction Tests}

The resultant disinfection of $E$. coli bacteria by silver under a range of chloride ion concentrations is shown in Figure 7. For both treatment concentrations of silver, disinfection is decreased with higher chloride ion concentration. Researchers observed the silver chloride $(\mathrm{AgCl})$ formation as a white precipitate in the batch reactors.
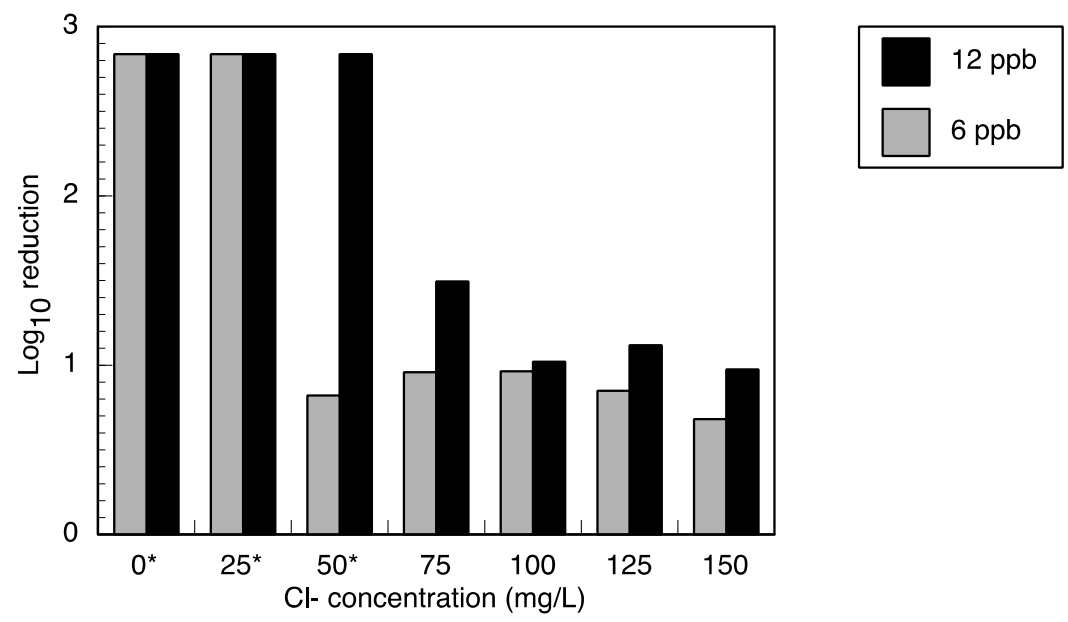

Figure 7. Reduction of $E$. coli bacteria by two concentrations of silver ions under a range of chloride ion concentrations (zero to $150 \mathrm{mg} / \mathrm{L}$ ). The batch reactors with a chloride concentration marked $\left(^{*}\right.$ ) may have higher disinfection as the treated samples did not detect any bacteria and the detection limit was used in the logarithmic reduction computation. Higher chloride concentrations decrease the disinfection of E. coli.

\subsection{Acceptance}

Researchers recorded students' consumption of water at primary schools in community A (Figure 8). Their water consumption behavior was measured by the number of times students drank 
water during the school day and whether they chose to drink the provided treated water or the standard water source. The standard drinking water sources in community A are $22 \mathrm{~L}$ plastic buckets with lids and shared cups that are placed outside every classroom. The buckets are filled with water from the central spigot in the school courtyard every morning. Students most often drank during snack time from 09:30 to 10:00. The treated water was not offered to students during the first week, T1; therefore, $100 \%$ of students drank from the standard water source. The students drank an average of 8.1 cups per 100 minutes during T1. When the treated water was offered, during the second (T2) and third (T3) weeks, students drank an average of 37.0 cups per 100 minutes including both treated and standard water source. This demonstrates a significant increase in the amount of drinking water consumed during the school day. Moreover, students overwhelmingly chose the treated water when it was offered, accounting for $90.0 \%$ of instances of water consumption during T2 and T3. Data are not available for the seventh grade students on days 12 (T2) or 18 (T3). On day 17 (T3), the grade seven treated water bucket was supposed to be filled by the students but was not filled until the morning due to a late sporting event on day 16. Because the treatment technology did not have the correct treatment time, $83 \%$ of seventh grade students chose to drink from the untreated water bucket on that day. Unprocessed observation journals are included as Document S2.

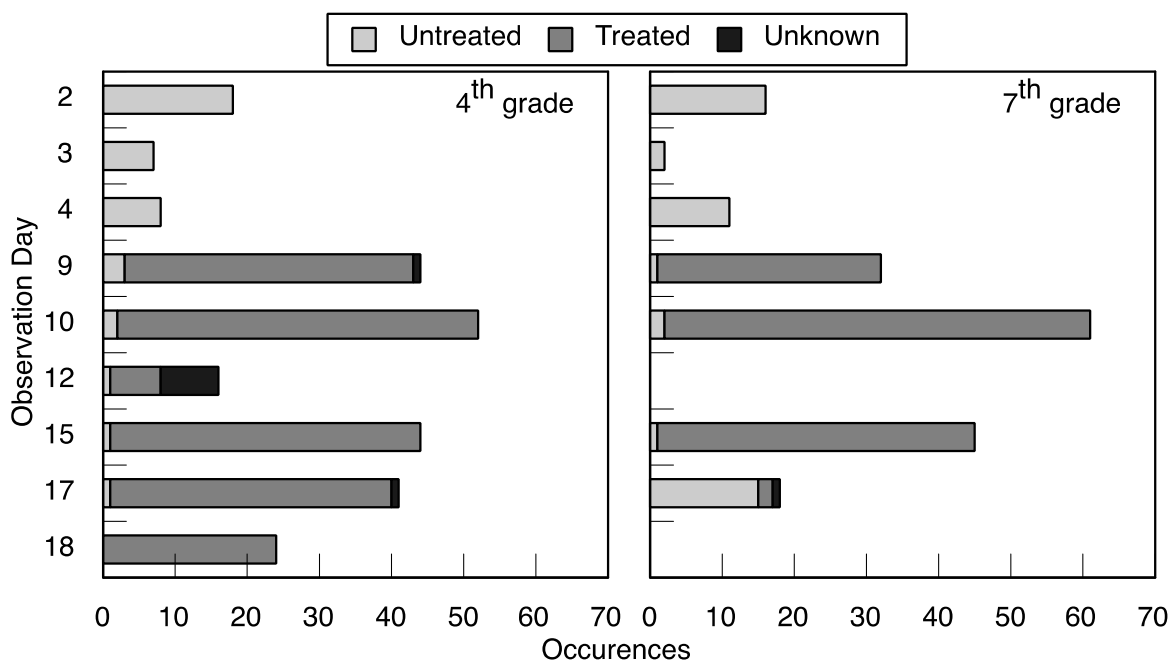

(a)

(b)

Figure 8. Results from (a) fourth grade and (b) seventh grade observation study in community A. Stacked column chart demonstrating occurrences of student consumption of drinking water. In T1 (days 2, 3, and 4), a treated option was not available; in T2 (days 9-18), students had access to their usual water supply as well as a bucket, with a lid and a spigot that contained the silver-impregnated porous ceramic pieces. Note that on days 12 and 18, the observation time was significantly shorter due to researcher traveling constraints. Data were not available from days 12 and 18 from seventh grade due to a change in classroom location.

\subsection{Priorities and Valuation}

Based on the survey of communities A and B, 59\% of the respondents do not routinely treat their drinking water (Figure 9). The common treatment methods are boiling water and chemical treatment. Chlorine was observed as the most common chemical used; in the South African communities, chlorine is frequently in the form of a bleach solution sold under the trade name, Jik; in the Tanzanian community, the government-funded health clinic distributes for free a commercial product called Water Guard to residents. In the South African communities (A and B), 59\% of community members retrieved their water using a cup with a handle, and $86 \%$ used any cup (with or without handle). In all communities surveyed, about one third do not store their water in a covered vessel. 

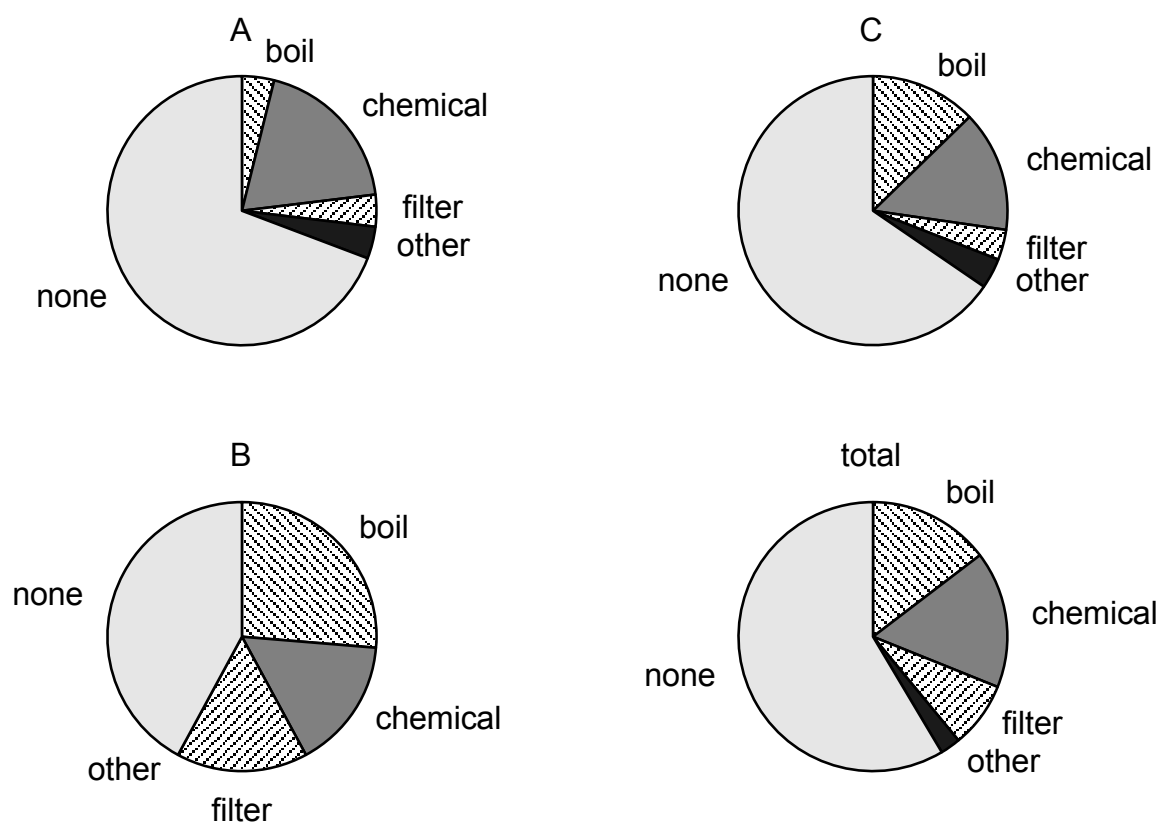

Figure 9. Self-reported water treatment practices from 50 households in each of the three communities. Researchers asked subjects, "What, if anything, do you use to treat your water?" in the vernacular. The majority of the population in all of the villages (59\%) does not routinely use any water treatment.

In communities $\mathrm{A}$ and $\mathrm{B}$, residents reported their top three most important characteristics for desirable water treatment technologies (Figure 10). The most desired characteristic was a good taste after treatment (18\% of responses). Cost of the technology (16\%) and quantity it can treat $(13 \%)$ were the next most important characteristics to residents. Few residents found ease of use (5\%) or ease of maintenance $(5 \%)$ of the water treatment technology to be important. All survey results are provided in Dataset S2.

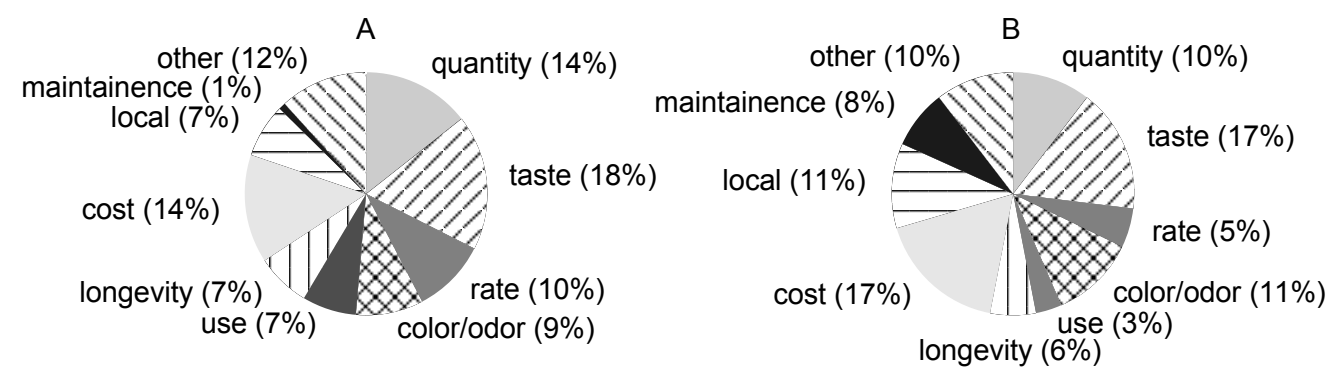

Figure 10. The most important characteristics of a water treatment technology as reported by 100 households in communities A and B (South Africa). Researchers asked subjects, "What are the three most important water treatment characteristics, in no particular order, to you and your family?" in the vernacular. The most important characteristic identified was taste of the treated water, although it was not statistically more important than price of the water treatment technology. The "other" category includes ease of use of the technology, ease of maintenance, and any other unlisted factors.

The results of the WTP portion of the surveys indicated that the majority of respondents in each price range were willing to pay to purchase the technology; however, the data do not resolve a specific price point. In community A, some respondents answered the question before prompted with a price range. Roughly one-third of respondents indicated they were not willing to pay when they were not provided with a price range (Figure 11). However, $100 \%$ of respondents indicated they were willing to pay below or above cost of production (Figure 11). Community A participants were slightly more likely 
to choose the highest option within any price range, but this trend was not observed in communities $\mathrm{A}$ or B (Figure 12). In community B, the proportion of participants not willing to pay at each price range remained less than $15 \%$. The greatest proportion of people in community $C$ that were willing to pay for the technology responded to the below and above cost price range. Slightly more than half of the respondents offered the at-cost price range stated that they were willing to pay (Figure 12).

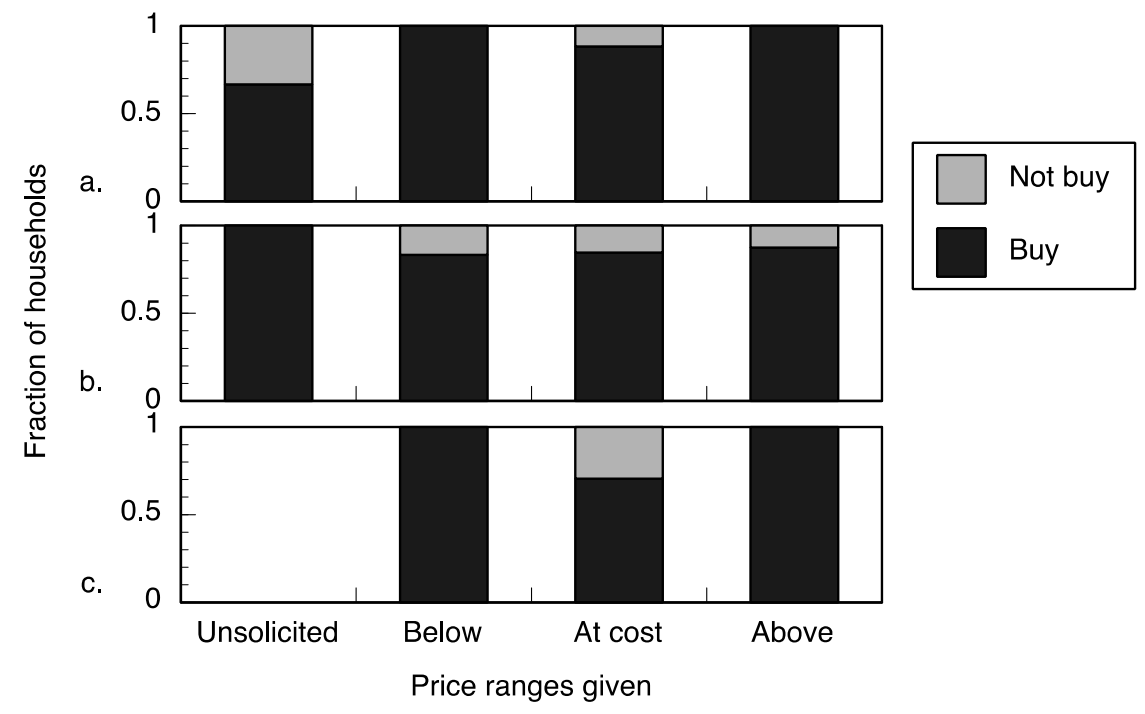

Figure 11. Responses to the question, "how much would you pay for this technology?" (willingness-to-pay) with three prices given, in descending order, or "would not purchase" in the vernacular at communities (a) A, (b) B, and (c) C. Any responses to price were aggregated as "buy" and negative responses were recorded as "not buy". The three ranges based on the cost of production of the product: below cost, at cost, and above cost. Houses were randomly assigned which range of prices would be asked and each range included three prices. The figure shows a willingness to pay in the above-cost range in all communities.

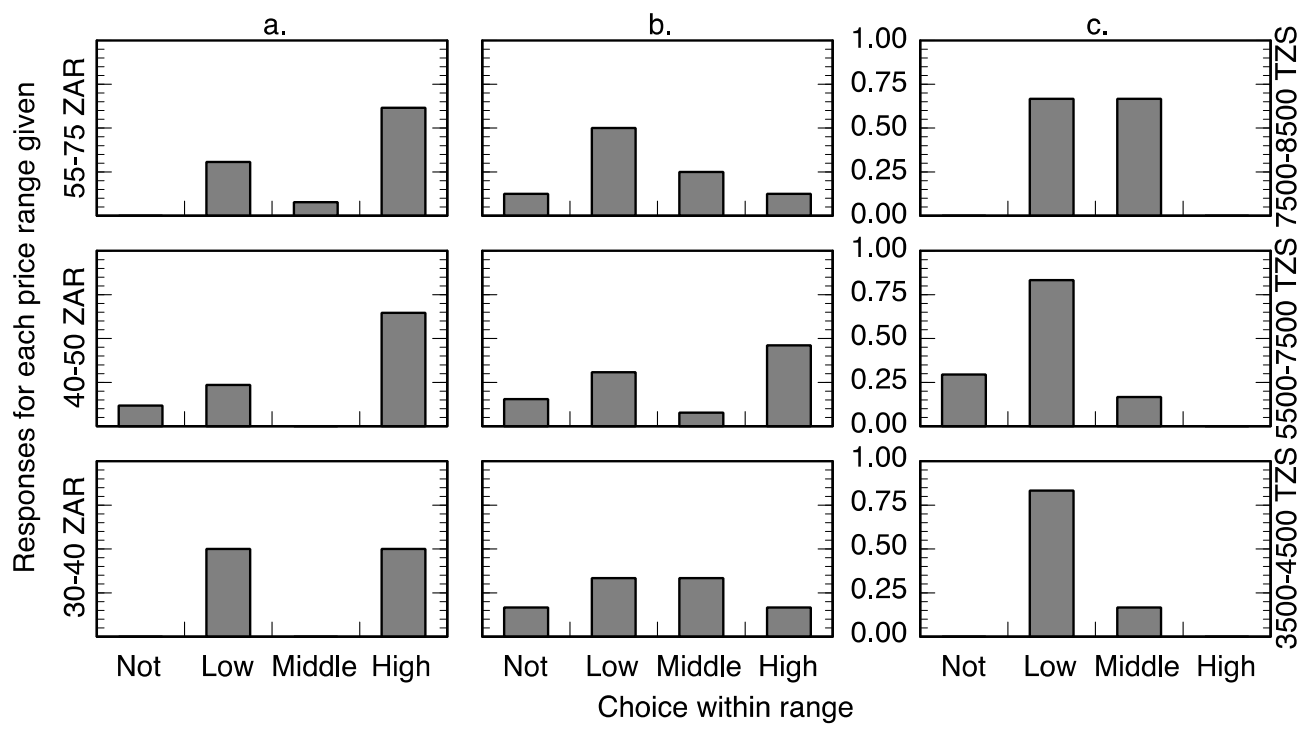

Figure 12. Responses to the question provided in the vernacular, "how much would you pay for this technology?" (willingness-to-pay) with three prices given, in descending order, or "would not purchase" in community A. The three ranges based on the cost of production of the product: below cost, at cost, and above cost. Each range had three prices. Houses were randomly assigned which range of prices would be asked and each range included three prices. 
In community A, only five people out of 50 surveyed came to the ceramic factory to purchase the ceramic technology, and they all claimed they had originally reported R30 as the price they would pay. This is likely because community members shared information between the days of sale that the standard rate was R30, and community members did not want to pay a higher price. One respondent who rejected all prices stated, without prompting, that he would reconsider a purchase if the South African Bureau of Standards evaluated the technology (as is common for commercialized products in South Africa).

In community $\mathrm{C}$, there were 10 members that purchased one ceramic technology for $6000 \mathrm{TZS}$. One community member chose to purchase two ceramic technologies for the reduced price of $10,000$ TZS. Four more community members received two technologies through the full-day ( $6 \mathrm{~h})$ work option. The largest purchasing group was 41 community members who received one technology in exchange for a half-day $(3 \mathrm{~h})$ of work. The work consisted of manual labor for the construction of a self-composting latrine project at the local school. Men who chose this option worked on laying cement and assisting with construction of the building. Women who chose this option carried buckets of sand, gravel, and cement bricks about $2 \mathrm{~km}$ to the construction site.

\section{Discussion}

This study measured the performance and acceptance of a silver-based point-of-use water treatment. The performance testing demonstrated that the water treatment is effective at coliform bacteria reduction of a factor of $10^{-3}-10^{-4}$ while maintaining safe levels of silver for human consumption. Both primary schools had minimal E. coli contamination. We present total coliform here to demonstrate the potential for bacterial removal in general. The reduction of all buckets that researchers filled to below detectible limits suggests additional training and care is required for ideal use. The overall disinfection levels are likely greater because the averages include the trials that brought the total coliform to below detectible limits (Figure 5). We did not detect a statistically significant relationship between the amount of silver in the water and the amount of disinfection.

The level of total coliform bacteria changed in community A over time. Researchers began measurements after a three-week school vacation. Figure 3 shows that the total coliform was high in the days after the vacation, which suggests that stagnant water in the school's tanks may have grown bacteria.

The source water used at both schools had turbidity within or close to drinking water standards. The water used in laboratory experiments had higher turbidity. The technology performed best when the water was of low turbidity whether naturally or diluted to a lower turbidity. Particles may interfere with disinfection by providing cracks and pores for bacteria to live that take longer for silver ions to diffuse into or by sorbing the silver ions before they can act upon microorganisms. Dissolved organic material was not measured but also may play a role in the action of the silver ions.

Trials in community $\mathrm{C}$ showed lower bacterial reduction than in community A; additionally, researchers measured high chloride concentrations in community $\mathrm{C}$. One possible explanation for this phenomenon is that the higher chloride levels caused insoluble silver chloride to precipitate. In laboratory experiments, silver ion (from silver nitrate) disinfection of E. coli was decreased with the addition of chloride (Figure 7). Silver chloride is less toxic to heterotrophic bacteria [35] and the insoluble form settles to the bottom of the batch reactor or bucket, where it does not mix effectively with the bulk water. Levard et al. [22] showed that dissolved silver from silver nanoparticles increased with chloride concentration; although, insoluble silver chloride preferentially formed followed by soluble silver chlorides, however, in deionized water, ionic silver was formed. Deionized water produced a similar amount of silver as the chloride mixture of molar ratio $\mathrm{Cl} / \mathrm{Ag} \approx 2675$ [22]. The chloride levels for the trials presented here were $1.0 \times 10^{4}$ in community A and $1.1 \times 10^{5}$ in community $\mathrm{C}$. Given the range of soluble silver formation determined by Lavard et al., the water from community $C$ should produce more soluble silver during treatment; however, it is hard to determine the disinfection activity because of confounding factors such as the types of silver chloride compounds formed (insoluble 
versus soluble) during treatment, large reaction vessel, and other ions present. Further work is needed to determine the behavior and disinfection potential of the technology under high ionic mixtures. Silver chloride precipitate was not recorded in the field trials; however, it would be nearly impossible to visualize the white precipitate because the buckets in community $C$ were white. The presence of chloride in community $\mathrm{C}$ may have reduced the overall bacterial reduction.

The acceptance testing at the local primary school indicated that students in fourth and seventh grade overwhelmingly chose the treated water when it was offered even before they were instructed on the function of the treatment method. This may indicate a bias towards choosing the novel option, but the students' persistent preference for the treated water over the remainder of the observation interval indicates its sustained acceptance, if not preference, amongst the students. The only day that students chose the untreated over the treated water was when the treatment bucket was not filled the night before, which students told researchers voluntarily. This observation day occurred after the educational intervention was delivered (during T3). While anecdotal, this indicates that students understood the limitations of the technology.

The surveys, answered by adult family members, revealed that most of respondents collect water from storage with a cup with handle and do not use any method of water treatment. The distinction between handle and no-handle is important because when the cups have a handle, bacteria on the water drinker's hand is less likely to touch the water. Researchers observed that many of the residents dipped a cup into the water storage container to drink, even when the storage container had a spigot. This may suggest that the residents had little knowledge of germ theory and the contamination they were causing by putting their hands into the drinking water. Respondents indicated that they regarded taste of water, cost of water treatment, and treatable quantity as the three most important characteristics in a potential water treatment technology. The silver-impregnated porous ceramic has an advantage because it imparts no taste to water, treats the average amount of water required by one family in a day (15 L), and costs roughly 3 USD to produce. Though education and income levels varied across the communities, the majority of respondents indicated they were willing to pay for technology at or above the production cost, which suggests that a sustainable and scalable business model is possible.

Given the option to purchase a product at three prices, as we provided in the willingness-to-pay survey, bias is possible if consumers choose a lower price in an attempt to purchase the product at a lower price in the future. This did not occur in community A. While the sample size is not large enough to generalize, potential consumers chose higher prices, which may indicate a stronger willingness-to-pay at a higher price. This result could be explained by the higher socioeconomic status of community A (Figure S2).

While there were few people who attempted to purchase the technology (willingness-to-buy), there were many confounding factors in community A. The ceramic factory where sales were offered was located on the edge of the community; it is possible that community members did not have the time or energy to walk 30 minutes each way to make the purchase. People in community A live on monthly salaries and are paid on the last day of the month. Many community members may not have had available or budgeted funds due to the timing of the sales.

Many members of community $\mathrm{C}$ purchased the technology. This may have also been affected by several factors. Respondents in community $\mathrm{C}$ were offered more buying options including being able to work rather than pay money and also receiving a discount for multiple unit purchases. Additionally, the location of sales was more centrally located to members of community $C$.

The U.S. Environmental Protection Agency (EPA) secondary drinking water standard for silver is set at $100 \mathrm{ppb}\left(10^{-4} \mathrm{~kg} \mathrm{~m}^{-3}\right)$ [36] and this technology delivers a dose of silver that is below half of this level. This level was determined based on a review of the literature of ingested silver. Silver accumulates and resides primarily in the skin and liver, although can be found in lower concentrations in other organs; however, there appears to be a half-life in the body of up to 50 days [37]. The adverse effect of silver consumption is argyria: a condition where the skin turns blue-gray [38], other adverse effects occur at higher doses. The World Health Organization has not officially published a guideline 
value for silver due to inadequate data; however, they cite the same no observed adverse effect level (NOAEL) as the U.S. EPA, based on argyria, and suggest that $100 \mathrm{ppb}$ in drinking water will yield an accumulation of half of the NOAEL value over 70 years of use.

High concentrations of silver can affect intestinal microbiota, which includes beneficial bacteria. Williams et al. [39] found that rats dosed with $9-400 \mathrm{mg} /$ day $\left(1.04 \times 10^{-10}\right.$ to $\left.4.63 \times 10^{-9} \mathrm{~kg} \mathrm{~s}^{-1}\right) \mathrm{per}^{-6}$ $\mathrm{kg}$ body weight of metallic silver had decreased levels of beneficial intestinal bacteria. We showed here that the silver-impregnated ceramic disk delivers less than 50 ppb of silver, which is less than half of the drinking water standard designed to protect against argyria. As a comparison, a $50 \mathrm{~kg}$ human that consumes an extraordinary $10 \mathrm{~L}\left(10^{-2} \mathrm{~m}^{3}\right)$ of treated drinking water will consume less than $0.01 \mathrm{mg} /$ day per $\mathrm{kg}$ body weight, which is a factor of $10^{-3}-10^{-4}$ less than the amount that altered the rat's microbiota (adjusted for body weight). The silver concentration delivered by the silver-impregnated ceramic technology is significantly lower than this level and below the drinking water standard and recommendation discussed here.

The silver ion concentration in the treated water because the solution, either directly from the treatment vessel or as human waste effluent, will likely be diluted to near the detection limit and near the typical environmental background [38]. Disposal of the technology could introduce a silver source into the environment; however, we feel that this dose will be inconsequential. Nevertheless, we recommend that the cubes not be discarded in aquatic environments. Recycling may also be an option in the future; however, this is an area of future research.

Research on environmental fate and animal toxicity has been limited and largely focused on the presence of silver nanoparticles themselves. As previously described, silver nanoparticles in this product are bonded to the ceramic matrix, which makes them generally unavailable for transport in the environment or consumption by animals. Coleman et al. [40] investigated the introduction of silver nanoparticles into planter boxes in the form of a biosolid mixture with added silver nanoparticles. The soil microbial community changed compared to the control trials and $\mathrm{N}_{2} \mathrm{O}$ flux from the soil increased. The overall plant biomass did not change significantly; however, the biomass of specific species was altered. The experiments were based on $0.14 \mathrm{mg} \cdot \mathrm{Ag} \cdot \mathrm{kg}^{-1}$ soil $\left(1.4 \times 10^{-7} \mathrm{Ag} / \mathrm{soil}\right)$, which is not directly comparable to the silver-impregnated ceramic cubes for two reasons. First, the silver nanoparticles are bonded to the ceramic matrix and not free to move about the soil. Second, because the silver nanoparticles are within the ceramic matrix, the production of silver ions and delivery outside the ceramic is rate limited by diffusion of oxidants into and silver out of the pore spaces. Nevertheless, even low silver ion concentrations can prove hazardous for very small aquatic animals. Febrega et al. [41] reviewed pertinent literature on silver nanoparticles in aquatic environments and reported that some freshwater fish species are susceptible to silver ion concentrations as low as $800 \mathrm{ppb}$. Since our treated water concentrations are over one order of magnitude less than this level, this is unlikely to present a significant hazard.

The results from this study indicate that this novel ceramic water treatment technology is effective, safe, acceptable, and appropriate for the study communities. Indeed, the silver-impregnated porous ceramic technology is appropriate to treat contaminated water that has low turbidity (limits on dissolved matter requires additional studies) and low chloride levels. The economic data suggest that most households are willing to pay for the technology at a rate that could support a business model distribution; however, some communities may need alternative purchasing options such as installments or work options. This could be a role that non-governmental, charitable, and aid organizations could play to provide flexible purchasing or work options. Future studies can examine the potential to scale-up sales to new communities, regions, and countries where environmental enteropathy remains an issue that is unresolved by current water treatment technologies.

Supplementary Materials: The following are available online at http://www.mdpi.com/2073-4441/8/3/95/S1. Figure S1: The age distribution by sex of community A (a) and B (b), and age distribution of community C (c). Less than $4 \%$ of individuals declined to report sex; however, nearly $20 \%$ of individuals would not or reported that they could not accurately report age of household members. Figure S2: Annual income in communities A, $\mathrm{B}$ and $\mathrm{C}$ in South African Rand (ZAR). There is a significant difference in the distribution of income between 
the sites. The income distribution from communities A and B skew to the higher ranges while the distribution from community $\mathrm{C}$ skews to the lower end of the range. Furthermore, of the 31 respondents in the community $\mathrm{C}$ who reported income in the "under 850 ZAR" range, 21 reported an annual income of zero. Table S1: Level of education completed by adult members of the household that were no longer in school. Data were self-reported during of adults in surveyed households. Document S1: Lesson plan from the educational intervention delivered in the fourth and seventh grade classrooms in the primary school in community A. Document S2: Unprocessed observation journals from community A drinking water and hygiene behavior monitoring. Dataset S1: Data from performance testing at primary schools in communities $\mathrm{A}$ and $\mathrm{C}$ and laboratory experiments as comma-separated values. Dataset S2: Survey responses from all communities as comma-separated values. The header line contains the survey question in English. Dataset S3: Water quality testing data from the Tanzania Ministry of Water. Includes population. Water quality testing was performed at a different time of year than our testing; although, the chloride levels remained high.

Acknowledgments: The authors thank the members of the communities where we worked for their hospitality and generosity with their time.

The project described was supported in part by the Fogarty International Center (FIC) of the National Institutes of Health (NIH) Award Number D43 TW009359; the National Science Foundation (NSF) Award Number CBET-1438619 and the NSF Research Experience for Undergraduates (REU) Award EEC 1156999; and the University of Virginia's Jefferson Public Citizens (JPC) program. The content is solely the responsibility of the authors and does not necessarily represent the official views of FIC, NIH, NSF, or the United States Government, or JPC. Open access fees were paid with funds from FIC.

The authors acknowledge Beeta Ehdaie and Rekha Singh, who provided extensive support and training, and Kathryn Nunnelley, who performed laboratory work at both University of Virginia and Venda, and supervised research assistants. Furthermore, Sheetal Sekhri, Department of Economics, University of Virginia, was instrumental in the development of the economic study. The authors also acknowledge University of Virginia students: Samuel Campbell, Charlotte Delaney, Mark Duda, and Rosemary O'Hagen, and University of Venda students: Khutji Matlala and Mulalo Mudau, who performed the field research; and University of Virginia students Emily Beacham and Benjamin Fry, who performed the chloride ion analysis. In Tanzania, the authors thank the Anglican Diocese of Central Tanganyika, the Carpenters' Kids program, and their local parish who introduced the research team to the community, hosted the research team, arranged transportation and interpreters, and provided laboratory space, and Francis Njau and the Institute of Rural Development Planning who provided research support and assistants in the communities.

Author Contributions: David M. Kahler developed the research protocol and supervised the research in both field sites led the analysis of the data, and contributed to writing the manuscript. Natasha T. Koermer and Allison R. Reichl performed research in the South Africa sites, analyzed data, and contributed to writing the manuscript. Amidou Samie managed the Institutional Review Board protocol at the University of Venda, facilitated research assistants in South Africa, contributed laboratory space and resources, and mentored the research team. James A. Smith is the principal investigator for the National Science Foundation award and NSF Research Experience for Undergraduates award that funded this work, supervised the overall work in South Africa, and has a long-standing relationship with the University of Venda and communities; he facilitated the work with the South African partners.

Conflicts of Interest: David M. Kahler, Natasha T. Koermer, Allison R. Reichl, and Amidou Samie declare no conflict of interest. James A. Smith has a potential conflict of interest. James A. Smith is the inventor of this technology, which was developed through research activities at the University of Virginia. James A. Smith has participated in the NSF I-Corp program (contract IIP 1313546) and is now substantially involved in a company to commercialize this technology. James A. Smith did not design this study or analyze any of the data. David M. Kahler made the decision to publish the results and led the analysis.

\section{Abbreviations}

The following abbreviations are used in this manuscript:

$\begin{array}{ll}\text { TCB } & \text { Total coliform bacteria } \\ \text { POU } & \text { Point-of-use [drinking water treatment] } \\ \text { IRB } & \text { Institutional Review Board } \\ \text { NTU } & \text { Nephelometric turbidity units } \\ \text { LB } & \text { Luria-Bertani [broth] } \\ \text { PB } & \text { Phosphate buffer } \\ \text { CFU } & \text { Colony-forming units } \\ \text { USD } & \text { United States Dollar } \\ \text { ZAR } & \text { South African Rand } \\ \text { TZS } & \text { Tanzanian Shilling }\end{array}$




$\begin{array}{ll}\text { FIC } & \text { Fogarty International Center (of the NIH) } \\ \text { NIH } & \text { National Institutes of Health } \\ \text { NSF } & \text { National Science Foundation } \\ \text { REU } & \text { Research Experience for Undergraduates } \\ \text { JPC } & \text { [the University of Virginia] Jefferson Public Citizens }\end{array}$

\section{References}

1. Lorntz, B.; Soares, A.M.; Moore, S.R.; Pinkerton, R.; Gansneder, B.; Bovbjerg, V.E.; Guyatt, H.; Lima, A.M.; Guerrant, R.L. Early childhood diarrhea predicts impaired school performance. Pediatr. Infect. Dis. J. 2006, 25, 513-520. [CrossRef] [PubMed]

2. Lopez, A.D.; Mathers, C.D.; Ezzati, M.; Jamison, D.T.; Murray, C.J.L. Global and regional burden of disease and risk factors, 2001: Systematic analysis of population health data. Lancet 2006, 367, 1747-1757. [CrossRef]

3. Niehaus, M.; Moore, S.; Patrick, P.; Derr, L.; Lorntz, B.; Lima, A.; Guerrant, R. Early childhood diarrhea is associated with diminished cognitive function 4 to 7 years later in children in a northeast Brazilian shantytown. Am. J. Trop. Med. Hyg. 2002, 66, 590-593. [PubMed]

4. Humphrey, J.H. Child undernutrition, tropical enteropathy, toilets, and handwashing. Lancet Lond. Engl. 2009, 374, 1032-1035. [CrossRef]

5. Korpe, P.S.; Petri, W.A. Environmental enteropathy: Critical implications of a poorly understood condition. Trends Mol. Med. 2012, 18, 328-336. [CrossRef] [PubMed]

6. Checkley, W.; Epstein, L.; Gilman, R.; Black, R.; Cabrera, L.; Sterling, C. Effects of Cryptosporidium parvum infection in Peruvian children: Growth faltering and subsequent catch-up growth. Am. J. Epidemiol. 1998, 148, 497-506. [CrossRef] [PubMed]

7. Clasen, T.; Schmidt, W.-P.; Rabie, T.; Roberts, I.; Cairncross, S. Interventions to improve water quality for preventing diarrhoea: Systematic review and meta-analysis. BMJ 2007, 334, 782-782. [CrossRef] [PubMed]

8. WHO. Evaluating Household Water Treatment Options: Health-Based Targets and Microbiological Performance Specifications; World Health Organization: Geneva, Switzerland, 2011; Available online: http://www.who.int/water_sanitation_health/publications/2011/evaluating_water_treatment.pdf (accessed on 10 November 2015).

9. Ren, D.; Colosi, L.M.; Smith, J.A. Evaluating the sustainability of ceramic filters for point-of-use drinking water treatment. Environ. Sci. Technol. 2013, 47, 11206-11213. [CrossRef] [PubMed]

10. MIT. Household Water Filter Evaluation; Comprehensive Initiative on Technology Evaluation at the Massachusetts Institute of Technology: Cambridge, MA, USA, 2015; Available online: http:/ / cite.mit.edu/ reports/water-filter-evaluation\# (accessed on 10 November 2015).

11. Ren, D.; Smith, J.A. Retention and transport of silver nanoparticles in a ceramic porous medium used for point-of-use water treatment. Environ. Sci. Technol. 2013, 47, 3825-3832. [CrossRef] [PubMed]

12. Smith, J.A.; Ehdaie, B.; Krause, C. Porous Metal Ceramic Materials and Methods for Making and Using the Same. U.S. Patent WO 2014071346 A1, 8 May 2014.

13. Pollini, M.; Paladini, F.; Catalano, M.; Taurino, A.; Licciulli, A.; Maffezzoli, A.; Sannino, A. Antibacterial coatings on haemodialysis catheters by photochemical deposition of silver nanoparticles. J. Mater. Sci. Mater. Med. 2011, 22, 2005-2012. [CrossRef] [PubMed]

14. Seil, J.T.; Webster, T.J. Antimicrobial applications of nanotechnology: Methods and literature. Int. J. Nanomedicine 2012, 7, 2767-2781. [PubMed]

15. Xiu, Z.; Zhang, Q.; Puppala, H.L.; Colvin, V.L.; Alvarez, P.J.J. Negligible particle-specific antibacterial activity of silver nanoparticles. Nano Lett. 2012, 12, 4271-4275. [CrossRef] [PubMed]

16. Ehdaie, B. Development of a Porous Ceramic Tablet Embedded with Silver Nanopatches for Low-Cost Point-of-Use Water Purification. Ph.D. dissertation, University of Virginia, Charlottesville, VA, USA, 2015.

17. Abebe, L.S.; Smith, J.A.; Narkiewicz, S.; Oyanedel-Craver, V.; Conaway, M.; Singo, A.; Amidou, S.; Mojapelo, P.; Brant, J.; Dillingham, R. Ceramic water filters impregnated with silver nanoparticles as a point-of-use water-treatment intervention for HIV-positive individuals in Limpopo Province, South Africa: A pilot study of technological performance and human health benefits. J. Water Health 2014, 12, 288-300. [CrossRef] [PubMed] 
18. Su, Y.; Tsegaye, M.; Varhue, W.; Liao, K.; Abebe, L.S.; Smith, J.A.; Guerrant, R.; Swami, N.S. Quantitative dielectrophoretic tracking for characterization and separation of persistent subpopulations of Cryptosporidium parvum. Analyst 2013. [CrossRef] [PubMed]

19. Abebe, L.S.; Su, Y.-H.; Guerrant, R.L.; Swami, N.S.; Smith, J.A. Point-of-Use Removal of Cryptosporidium parvum from Water: Independent Effects of Disinfection by Silver Nanoparticles and Silver Ions and by Physical Filtration in Ceramic Porous Media. Environ. Sci. Technol. 2015, 49, 12958-12967. [CrossRef] [PubMed]

20. Elechiguerra, J.L.; Burt, J.L.; Morones, J.R.; Camacho-Bragado, A.; Gao, X.; Lara, H.H.; Yacaman, M.J. Interaction of silver nanoparticles with HIV-1. J. Nanobiotechnol. 2005, 3, 6. [CrossRef] [PubMed]

21. Cheng, Y.; Chen, X.; Song, W.; Kong, Z.; Li, P.; Liu, Y. Contribution of silver ions to the inhibition of infectivity of Schistosoma japonicum cercariae caused by silver nanoparticles. Parasitology 2013, 140, 617-625. [CrossRef] [PubMed]

22. Levard, C.; Mitra, S.; Yang, T.; Jew, A.D.; Badireddy, A.R.; Lowry, G.V.; Brown, G.E. Effect of chloride on the dissolution rate of silver nanoparticles and toxicity to E. coli. Environ. Sci. Technol. 2013, 47, 5738-5745. [CrossRef] [PubMed]

23. Liu, J.; Hurt, R.H. Ion release kinetics and particle persistence in aqueous nano-silver colloids. Environ. Sci. Technol. 2010, 44, 2169-2175. [CrossRef] [PubMed]

24. Oyanedel-Craver, V.A.; Smith, J.A. Sustainable Colloidal-Silver-Impregnated Ceramic Filter for Point-of-Use Water Treatment. Environ. Sci. Technol. 2008, 42, 927-933. [CrossRef] [PubMed]

25. Firth, J.; Balraj, V.; Muliyil, J.; Roy, S.; Rani, L.M.; Chandresekhar, R.; Kang, G. Point-of-use interventions to decrease contamination of drinking water: A randomized, controlled pilot study on efficacy, effectiveness, and acceptability of closed containers, Moringa oleifera, and in-home chlorination in rural South India. Am. J. Trop. Med. Hyg. 2010, 82, 759-765. [CrossRef] [PubMed]

26. Freeman, M.C.; Quick, R.E.; Abbott, D.P.; Ogutu, P.; Rheingans, R. Increasing equity of access to point-of-use water treatment products through social marketing and entrepreneurship: A case study in western Kenya. J. Water Health 2009, 7, 527-534. [CrossRef] [PubMed]

27. Jacob, A.; Ramani, S.; Banerjee, I.; Kang, G. Efficacy and acceptability of chlorine dioxide water disinfectant. Indian J. Med. Microbiol. 2007, 25, 74-75. [PubMed]

28. Makutsa, P.; Nzaku, K.; Ogutu, P.; Barasa, P.; Ombeki, S.; Mwaki, A.; Quick, R.E. Challenges in implementing a point-of-use water quality intervention in rural Kenya. Am. J. Public Health 2001, 91, 1571-1573. [CrossRef] [PubMed]

29. Roberts, L.; Chartier, Y.; Chartier, O.; Malenga, G.; Toole, M.; Rodka, H. Keeping clean water clean in a Malawi refugee camp: A randomized intervention trial. Bull. World Health Organ. 2001, 79, 280-287. [PubMed]

30. Census 2001 Community Profile [DVD]; Statistics South Africa: Pretoria, South Africa, 2001.

31. Wazara ya Maji wa Tanzania (Tanzania Ministry of Water). WSDP Chamwino Villages. Unpublished data. 2015.

32. Ehdaie, B.; Krause, C.; Smith, J.A. Porous ceramic tablet embedded with silver nanopatches for low-cost point-of-use water purification. Environ. Sci. Technol. 2014, 48, 13901-13908. [CrossRef] [PubMed]

33. Ehdaie, B.; Rento, C.T.; Turner, S.S.; Samie, A.; Dillingham, R.A.; Smith, J.A. Evaluation of silver-embedded ceramic tablet as a primary and secondary point- of-use water purification technology in Limpopo Province, S. Africa. Unpublished work. 2016.

34. Danford, E.; (Dodoma, Tanzania). Personal communication, 2015.

35. Choi, O.; Deng, K.K.; Kim, N.-J.; Ross, L.; Surampalli, R.Y.; Hu, Z. The inhibitory effects of silver nanoparticles, silver ions, and silver chloride colloids on microbial growth. Water Res. 2008, 42, 3066-3074. [CrossRef] [PubMed]

36. United States Environmental Protection Agency. Secondary drinking water standards: guidance for nuisance chemicals. Available online: http:/ / www.epa.gov/dwstandardsregulations/secondary-drinkingwater-standards-guidance-nuisance-chemicals (accessed 22 February 2016).

37. WHO. Guidelines for Drinking-Water Quality_Volume 2: Health Criteria and other Supporting Information, 2nd ed.; World Health Organization: Geneva, Switzerland, 1996.

38. EPA. Silver; CASRN 7440-22-4: Integrated Risk Information System, Chemical Assessment Summary; United States Environmental Agency, National Center for Environmental Assessment: Washington, DC, USA, 1991. 
39. Williams, K.; Milner, J.; Boudreau, M.D.; Gokulan, K.; Cerniglia, C.E.; Khare, S. Effects of subchronic exposure of silver nanoparticles on intestinal microbiota and gut-associated immune responses in the ileum of Sprague-Dawley rats. Nanotoxicology 2015, 9, 279-289. [CrossRef] [PubMed]

40. Colman, B.P.; Arnaout, C.L.; Anciaux, S.; Gunsch, C.K.; Hochella, M.F.; Kim, B.; Lowry, G.V.; McGill, B.M.; Reinsch, B.C.; Richardson, C.J.; et al. Low concentrations of silver nanoparticles in biosolids cause adverse ecosystem responses under realistic field scenario. PLoS ONE 2013, 8, e57189. [CrossRef] [PubMed]

41. Fabrega, J.; Luoma, S.N.; Tyler, C.R.; Galloway, T.S.; Lead, J.R. Silver nanoparticles: Behaviour and effects in the aquatic environment. Environ. Int. 2011, 37, 517-531. [CrossRef] [PubMed]

(C) 2016 by the authors; licensee MDPI, Basel, Switzerland. This article is an open access article distributed under the terms and conditions of the Creative Commons by Attribution (CC-BY) license (http://creativecommons.org/licenses/by/4.0/). 